\title{
Substance P (Neurokinin 1) Receptor Antagonists Enhance Dorsal Raphe Neuronal Activity
}

\author{
Rachel K. Conley, Michael J. Cumberbatch, Glenn S. Mason, David J. Williamson, Timothy Harrison, \\ Karen Locker, Christopher Swain, Karen Maubach, Ruth O’Donnell, Michael Rigby, Louise Hewson, \\ David Smith, and Nadia M. J. Rupniak
}

Departments of Pharmacology and Medicinal Chemistry, Merck Sharp and Dohme Neuroscience Research Centre, Harlow, Essex CM20 2QR, United Kingdom

\begin{abstract}
Substance $\mathrm{P}$ receptor [neurokinin $1\left(\mathrm{NK}_{1}\right)$ ] antagonists (SPAs) represent a novel mechanistic approach to antidepressant therapy with comparable clinical efficacy to selective serotonin reuptake inhibitors (SSRIs). Because SSRIs are thought to exert their therapeutic effects by enhancing central serotonergic function, we have examined whether SPAs regulate neuronal activity in the dorsal raphe nucleus (DRN), the main source of serotonergic projections to the forebrain. Using in vivo electrophysiological techniques in the guinea pig, we found that administration of the highly selective $\mathrm{NK}_{1}$ receptor antagonist 1-(5-\{[(2R,3S)-2-(\{(1R)-1-[3,5-bis(trifluoromethyl)phenyl]]ethyl\}oxy)3-(4-phenyl)morpholin-4-yl]methyl\}-2H-1,2,3-triazol-4-yl)-N,Ndimethylmethanamine (L-760735) caused an increase in DRN neuronal firing rate. However, unlike chronic treatment with fluoxetine, there was no detectable 5- $\mathrm{HT}_{1 \mathrm{~A}}$ autoreceptor desensitization. In vitro electrophysiological investigation showed
\end{abstract}

Abnormalities in central 5-HT neurotransmission are associated with anxiety and depression. Clinically effective antidepressant drugs such as the selective serotonin reuptake inhibitors (SSRIs) fluoxetine and paroxetine are thought to exert their therapeutic effects by facilitating 5-HT function (Bel and Artigas, 1993). This is believed to occur, in part, at the level of the dorsal raphe nucleus (DRN) where SSRIs cause a functional desensitization of $5-\mathrm{HT}_{1 \mathrm{~A}}$ autoreceptors, leading to an increase in 5-HT neuronal activity (Blier and de Montigny, 1994; Jolas et al., 1994). Because the DRN is the major source of ascending 5-HT projections (Vertes, 1991), this is believed to increase forebrain levels of 5-HT.

However, the therapeutic efficacy of SSRIs is limited by their side-effect profile and the delay in clinical benefit associated with their use, and so there is a pressing need for a new class of antidepressant drug. This need may be fulfilled by neurokinin 1 $\left(\mathrm{NK}_{1}\right)$ receptor antagonists. In preclinical studies, pharmacological blockade or genetic deletion of $\mathrm{NK}_{1}$ receptors has produced effects similar to those produced by antidepressant drugs by attenuating behavioral and neurochemical stress responses, in-

\footnotetext{
Received April 10, 2002; revised June 10, 2002; accepted June 12, 2002.

We thank Dr. R. Shigemoto (University of Kyoto, Kyoto, Japan) for his $\mathrm{NK}_{1}$ receptor fusion protein antibody, F. Kuenzi for writing the Spike2 analysis scripts, F. J. Kelleher and R. Frankshun for the synthesis of L-760735 and L-770765, and A. Wheeldon, N. Clarke, and G. Bentley for technical assistance.

Correspondence should be addressed to Nadia M. J. Rupniak, Merck Sharp and Dohme Neuroscience Research Centre, Terlings Park, Harlow, Essex CM20 2QR, UK. E-mail: Nadia_Rupniak@merck.com.

Copyright (C) 2002 Society for Neuroscience $\quad 0270-6474 / 02 / 227730-07 \$ 15.00 / 0$
}

that these effects were not mediated by a direct action in the DRN, an observation supported by immunocytochemical analysis that identified the lateral habenula $(\mathrm{LHb})$ as a more likely site of action. Subsequently, we found that local application of $\mathrm{L}-760735$ into the $\mathrm{LHb}$ increased firing in the DRN, which, together with our data showing that L-760735 increased metabolic activity in the cingulate cortex, amygdala, LHb, and DRN, indicates that the effects of L-760735 may be mediated by disinhibition of forebrain structures acting via a habenulo raphe projection. These findings support other evidence for an antidepressant profile of SPAs and suggest that regulation of DRN neuronal activity may contribute to their antidepressant mechanism of action but in a manner that is distinct from monoamine reuptake inhibitors.

Key words: dorsal raphe; $N K_{1}$ receptors; lateral habenula; depression; guinea pig; electrophysiology cluding neonatal vocalization (Kramer et al., 1998; Rupniak et al., 2000), aggression (Shaikh et al., 1993; de Felipe et al., 1998), shock-induced sensitization of the acoustic startle response (Krase et al., 1994), and activation of noradrenergic (Hahn and Bannon, 1999) and dopaminergic (Barton et al., 1999) neurons by restraint. Furthermore, in the clinic, the substance P (SP) antagonist (SPA) 5-[(2 $R)$-[1 $(R)$-[3,5-bis(trifluoromethyl)phenyl]ethoxy]- 3( $S$ )(4-fluorophenyl)-4-morpholinyl)methyl]-2,4-dihydro- ${ }^{3} \mathrm{H}-1,2,4$-triazol-3-one] (MK869) has produced therapeutically beneficial effects in patients with Major Depressive Disorder (Kramer et al., 1998). Because MK869 has no appreciable affinity for monoamine receptors, transporters, or monoamine oxidase and a different adverse event profile from paroxetine, these observations indicate that SPAs may provide a novel mechanistic approach to alleviate depression.

Anatomical evidence suggests a close link between SP and 5-HT systems in the brain, raising the possibility that SPAs influence central 5-HT function. For example, at the level of the DRN, SP is coexpressed with 5 -HT in $\sim 50 \%$ of neurons in humans (Baker et al., 1991; Sergeyev et al., 1999) and macaques (Charara and Parent, 1998), whereas experimental data from the rat indicate that SP regulates DRN neuronal activity via an inhibitory projection from the lateral habenula (LHb) (Neckers et al., 1979; Reisine et al., 1982), the principal relay in descending projections from the forebrain to the DRN (see Fig. 1 for schematic). Together, the data suggest that SPAs can influence DRN function, and so the present study was designed to examine the effects of SPA treatment on DRN neuronal activity using elec- 


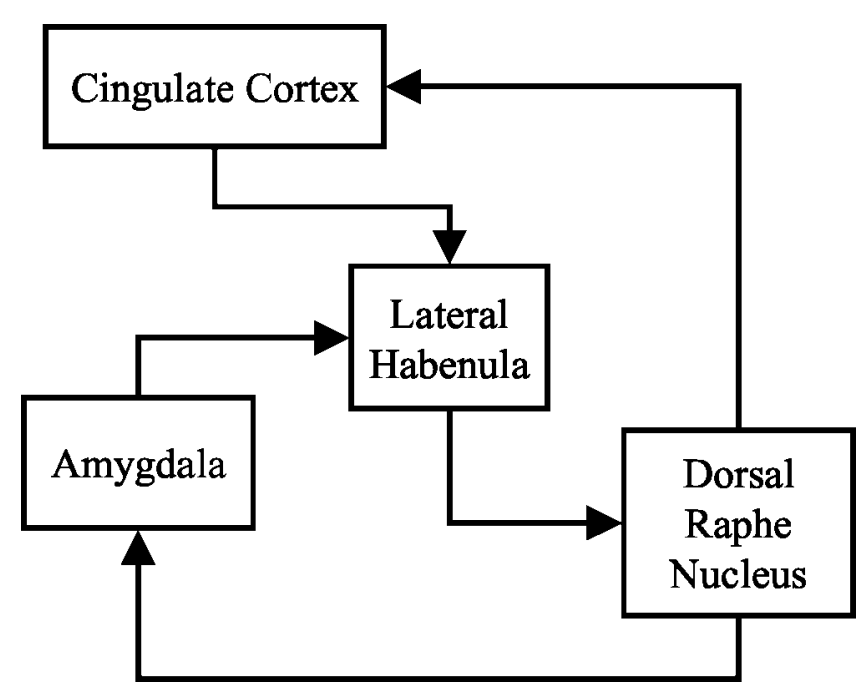

Figure 1. Simple schematic of proposed circuit mediating effects of SPAs on DRN activity. Each of the areas, with the exception of the DRN, contains high levels of $\mathrm{NK}_{1}$ receptors in the guinea pig and primate. All connections within this circuit are likely to be reciprocal.

trophysiological, neuroanatomical, and neurochemical techniques. Experiments were performed in guinea pigs because $\mathrm{NK}_{1}$ receptor pharmacology in this species resembles that in humans (Beresford et al., 1991; Gitter et al., 1991); the SPA used was $1-(5-\{[(2 R, 3 S)-2-(\{(1 R)-1-[3,5-b i s($ trifluoromethyl)phenyl]ethyloxy)-3-(4-phenyl)morpholin-4-yl]methyl $\}-2 H-1,2,3$-triazol-4-yl)$N, N$-dimethylmethanamine (L-760735), a selective and brain penetrant analog of MK869 with high affinity at the guinea pig $\mathrm{NK}_{1}$ receptor $\left(\mathrm{IC}_{50}, 0.34 \mathrm{nM}\right)$. The effects of $\mathrm{L}-760735$ were compared with those of its low-affinity analog 1-(5-\{[(2S,3R)-2-(\{(1S)1-[3,5-bis(trifluoromethyl)phenyl] ethyl $\}$ oxy)-3-(4-fluorophenyl) morpholin-4-yl]methyl $-2 H$-1,2,3,-triazol-4-yl) $N, N$-dimethylmethanamine (L-770765) $\left(\mathrm{IC}_{50}, 320 \mathrm{nM}\right)$ or its $(S)$-enantiomer $1-(5-\{[(2 S, 3 R)-2-(\{(1 S)-1-[3,5-$ bis(trifluoromethyl)phenyl] ethyl $\}$ oxy)-3-(4-phenyl)morpholin-4-yl]methyl]-2H-1,2,3-triazol4-yl)-N,N-dimethylmethanamine (L-781773) $\left(\mathrm{IC}_{50}, 545 \mathrm{~nm}\right)$ to control for nonspecific actions (Kramer et al., 1998).

\section{MATERIALS AND METHODS}

In vitro electrophysiological recordings from the DRN. Brain slices were prepared from male guinea pigs $(\sim 180 \mathrm{gm}$; Dunkin Hartley; Harlan, Bicester, UK). Coronal slices (400 $\mu \mathrm{m}$ thick) of the DRN were cut and then transferred to a recording chamber under continuous flow $(\sim 2$ $\mathrm{ml} / \mathrm{min})$ of artificial aerated $\left(95 \% \mathrm{O}_{2}\right.$ plus $\left.5 \% \mathrm{CO}_{2}\right) \mathrm{CSF}$ at $34^{\circ} \mathrm{C}$ [composition (in mM): $126 \mathrm{NaCl}, 2.5 \mathrm{KCl}, 1.2 \mathrm{NaH}_{2} \mathrm{PO}_{4}, 2.4 \mathrm{CaCl}_{2} .2$ $\mathrm{H}_{2} \mathrm{O}, 1.3 \mathrm{MgCl}_{2} \cdot 6 \mathrm{H}_{2} \mathrm{O}, 26 \mathrm{NaHCO}_{3}$, and 10 D-glucose, $\mathrm{pH}$ 7.4]. Conventional techniques were used to make intracellular current-clamp recordings using microelectrodes filled with K-acetate $(3 \mathrm{M})$.

In vivo electrophysiological recordings. Male Dunkin Hartley guinea pigs $(350-600 \mathrm{gm})$ were anesthetized with sodium pentobarbitone (60 $\mathrm{mg} / \mathrm{kg}$, i.p., followed by $40 \mathrm{mg} / \mathrm{kg}$ i.v. infusion), and electrophysiological recordings were made from the DRN using glass microelectrodes (filled with pontamine sky blue in $0.5 \mathrm{M}$ Na-acetate; $9.5-10 \mathrm{~mm}$ caudal to bregma and $6-8 \mathrm{~mm}$ deep). Cells with characteristics of 5-HT neurons were identified by their wide action potentials $(1.5-2 \mathrm{msec})$, slow regular firing rate $(0.5-5 \mathrm{~Hz})$, and inhibition by the $5-\mathrm{HT}_{1 \mathrm{~A}}$ agonist 8 -hydroxy2(di- $n$-propylamino)tetralin (8-OH-DPAT) $(10$ or $30 \mu \mathrm{g} / \mathrm{kg}$, i.v.; $n=23$ ). In acute studies, either L-760735 or L-770765 was administered (3 $\mathrm{mg} / \mathrm{kg}$, i.v.) after $10-15 \mathrm{~min}$ of stable unit activity. The dose of $3 \mathrm{mg} / \mathrm{kg}$ for L-760735 was based on dose-response studies in this species that establish this to be a maximally efficacious dose (Kramer et al., 1998). In chronic studies performed on the day after $28 \mathrm{~d}$ of once daily oral dosing with either vehicle, fluoxetine $\left(10 \mathrm{mg} \cdot \mathrm{kg}^{-1} \cdot \mathrm{d}^{-1}\right)$, or L-760735 (3 $\left.\mathrm{mg} \cdot \mathrm{kg}^{-1} \cdot \mathrm{d}^{-1}\right)$, the spontaneous DRN single neuronal firing rate was recorded and used to calculate the incidence of burst firing [more than or equal to two spikes with an interspike interval of $\leq 10 \mathrm{msec}$ as defined previously (Hajos et al., 1995)]. Cells were then tested with cumulative doses of 8 -OH-DPAT $(1-300 \mu \mathrm{g} / \mathrm{kg}$, i.v.) until $>70 \%$ inhibition was observed. $\mathrm{ID}_{50}$ values were calculated (Prism; GraphPad Software, San Diego, CA) and compared using a one-way ANOVA followed by Dunnett's $t$ tests. In microiontophoretic studies, L-760735 was applied locally into the $\mathrm{LHb}(5.4 \mathrm{~mm}$ caudal and $1.1 \mathrm{~mm}$ lateral to bregma, $5.7-5.8 \mathrm{~mm}$ ventral). The barrels of the pipette were filled with $5 \mathrm{~mm} \mathrm{~L}-760735$ or L-770765 (in $200 \mathrm{~mm} \mathrm{NaCl}$ at $\mathrm{pH} \mathrm{3.5;}-0.5 \mathrm{~V}$ retaining voltage) and pontamine sky blue ( $2 \%$ in $0.5 \mathrm{~m}$ Na-acetate). Either L-760735 or L-770765 was iontophoresed into the $\mathrm{LHb}$ at currents of up to $+80 \mathrm{nA}$, and the effects on DRN neuronal activity were recorded. After each experiment, pontamine sky blue was ejected $(-20 \mu \mathrm{A}, 2-5 \mathrm{~min})$ to mark the location of the DRN test cell and habenula injection site; the brain was subsequently removed, frozen, and sectioned $(20 \mu \mathrm{m})$ to verify correct electrode placement.

Immunocytochemical determination of $\mathrm{NK}_{1}$ receptor expression. For the purposes of comparison between rodent and primate species, the DRN and $\mathrm{LHb}$ from the guinea pig, primate, and rat were examined for $\mathrm{NK}_{1}$ receptor expression. DRN and $\mathrm{LHb}$ sections were blocked in 5\% normal goat serum in PBS plus $0.3 \%$ Triton X-100 (PBS + Tx) for $1 \mathrm{hr}$ before incubation with rabbit anti- $\mathrm{NK}_{1}$ receptor $(1: 5000)$ overnight at $+4^{\circ} \mathrm{C}$. Sections from rodent species were immunostained for $\mathrm{NK}_{1}$ receptor using an antibody raised to a synthetic 15 aa peptide sequence (SP receptor 393-407) corresponding to the $\mathrm{C}$ terminus of the rat $\mathrm{NK}_{1}$ receptor (Vigna et al., 1994). For primate tissues, the fusion protein antibody developed by Dr. R. Shigemoto (University of Kyoto, Kyoto, Japan) was used because it has been used successfully with human brain tissue (Cicchetti et al., 1996). Sections were washed in PBS + Tx and incubated in biotinylated goat anti-rabbit $\operatorname{IgG}(1: 200)$. After washes in $\mathrm{PBS}+\mathrm{Tx}$ and subsequent incubation in Elite ABC horseradish peroxidase complex, sections were developed in 3,3-diaminobenzidine $(0.25$ $\mathrm{mg} / \mathrm{ml}$ in PBS) for $5 \mathrm{~min}$. Once dried onto slides, sections were mounted and examined using bright field illumination on a Leica (Milton Keynes, UK) microscope.

Measurement of brain metabolic activity using $2-\left[{ }^{14} C(U)\right]$ deoxyglucose. To identify other midbrain and forebrain regions that might be affected by $\mathrm{NK}_{1}$ receptor blockade, regional increases in metabolic activity were measured by 2-DG utilization after acute administration of L-760735. Male guinea pigs were anesthetized (as described above) and cannulated to allow maintenance of blood gases within normal physiological range as described previously (Kurumaji and McCulloch, 1989). Vehicle $(n=4)$, $\mathrm{L}-760735$ (3 $\mathrm{mg} / \mathrm{kg} ; n=5)$, or its less active enantiomer L-781773 (3 $\mathrm{mg} / \mathrm{kg} ; n=6$ ) was administered intravenously followed 5 min later by a $10 \mu \mathrm{Ci}$ injection of 2-[ $\left.{ }^{14} \mathrm{C}(\mathrm{U})\right]$ deoxyglucose (PerkinElmer Life Sciences, Cambridge, UK). Serial blood samples were taken, and the animal was killed 45 min later with an overdose of anesthetic; brains were then removed, frozen, sectioned, and apposed to autoradiograph film (Hyperfilm bmax; Amersham Biosciences, Little Chalfont, UK). Glucose utilization was derived from the Sokoloff equation (Sokoloff et al., 1977). Values of plasma 2-deoxyglucose, glucose levels, and ${ }^{14} \mathrm{C}$ local brain concentrations read against known standards on an image analysis system (AIS Imaging Research Inc., St. Catherines, Canada) were inserted into the Sokoloff equation. Data are shown as mean \pm SEM. Statistical analyses were performed using a Student's $t$ test.

Effects of L-760735 on 5-HT receptors and transporters in vitro. Radioligand-binding assays were performed by Panlabs (Taipei, Taiwan) DiscoveryScreen using monoamine transporter assays as described previously (Berger et al., 1990; Cesura et al., 1990; Tejani-Butt et al., 1990; Boja et al., 1992).

\section{RESULTS}

\section{Effects of L-760735 on DRN neuronal activity in vitro}

Guinea pig DRN neurons were identified by their position within the in vitro slice and by their characteristic biophysical properties (membrane potential, $-74 \pm 4 \mathrm{mV}$; input resistance, $159 \pm 33$ $\mathrm{M} \Omega ; n=8)$. In the presence of tetrodotoxin $(0.5 \mu \mathrm{M})$, direct application of the 5-HT $1 \mathrm{~A}$ receptor agonist 8-OH-DPAT $(1 \mu \mathrm{M})$ caused a large hyperpolarization of DRN neurons $(-14 \pm 2 \mathrm{mV}$; $n=4)$, consistent with the direct activation of $5-\mathrm{HT}_{1 \mathrm{~A}}$ autoreceptors. In contrast, SP (500 nM; $n=7)$ or L-760735 (100 nм; $n=$ 


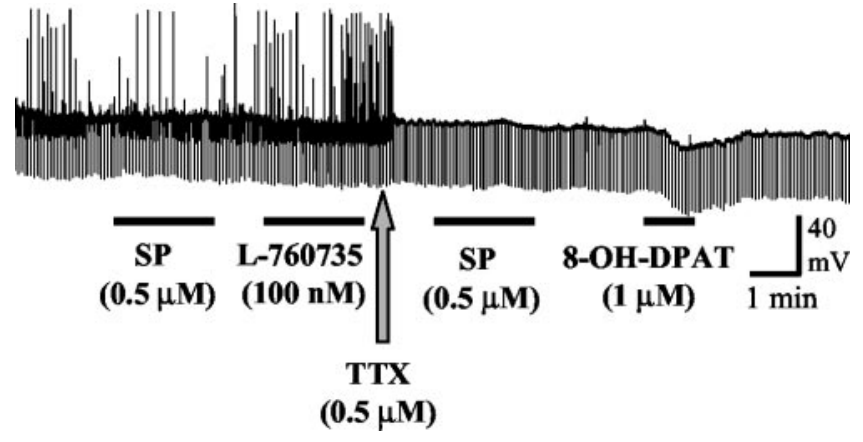

Figure 2. Effect of SP $(0.5 \mu \mathrm{M})$, the $\mathrm{NK}_{1}$ receptor antagonist L-760735 $(100 \mathrm{nM})$, and the $5-\mathrm{HT}_{1 \mathrm{~A}}$ receptor agonist 8 -OH-DPAT $(1 \mu \mathrm{M})$ on a guinea pig DRN neuron in vitro. The trace is an intracellular recording of membrane potential, the upward deflections are spontaneous action potentials that were abolished in the presence of tetrodotoxin (TTX, 0.5 $\mu \mathrm{M}$ ), and the downward deflections are responses to injection of negative current pulses used to monitor neuronal input resistance. Although 8-OH-DPAT caused a hyperpolarizing response consistent with the activation of $5-\mathrm{HT}_{1 \mathrm{~A}}$ autoreceptors, SP and L-760735 had no effect on membrane potential or input resistance, suggesting that $\mathrm{NK}_{1}$ receptors are not present in the guinea pig DRN.

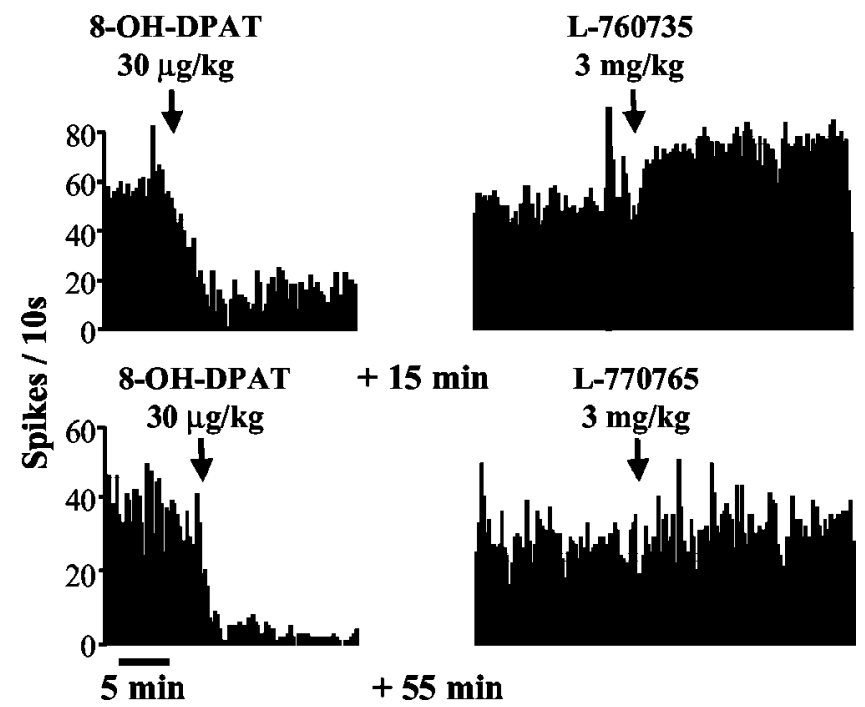

Figure 3. Effects of acute administration of the $5-\mathrm{HT}_{1 \mathrm{~A}}$ receptor agonist 8-OH-DPAT $(30 \mu \mathrm{g} / \mathrm{kg})$ or the $\mathrm{NK}_{1}$ receptor antagonist L-760735 (3 $\mathrm{mg} / \mathrm{kg}$ ) on DRN neuronal firing. In cells that were inhibited by $8-\mathrm{OH}-$ DPAT, L-760735 caused a marked facilitation of firing rate, whereas L-770765 (the low-affinity analog of L-760735) had no effect.

3) had no effect on either the membrane potential or input resistance in the same neurons (Fig. 2).

\section{Effects of L-760735 on DRN neuronal activity in vivo Acute studies}

Intravenous administration of L-760735 (3 mg/ $\mathrm{kg}$ ) caused an approximate doubling of the firing rate $(86 \pm 12 \%$ increase; $n=$ 5) that lasted $>1 \mathrm{hr}$; administration of the same dose of L-770765 had no effect on DRN neuronal activity $(+11 \pm 5 \% ; n=4)$ (Fig. 3 ). Burst firing was not observed after acute administration of L-760735 (percentage of events in bursts occurring before and after injection of L-760735: $0.81 \pm 0.45$ and $1.1 \pm 0.67$, respectively; $n=6$ ).

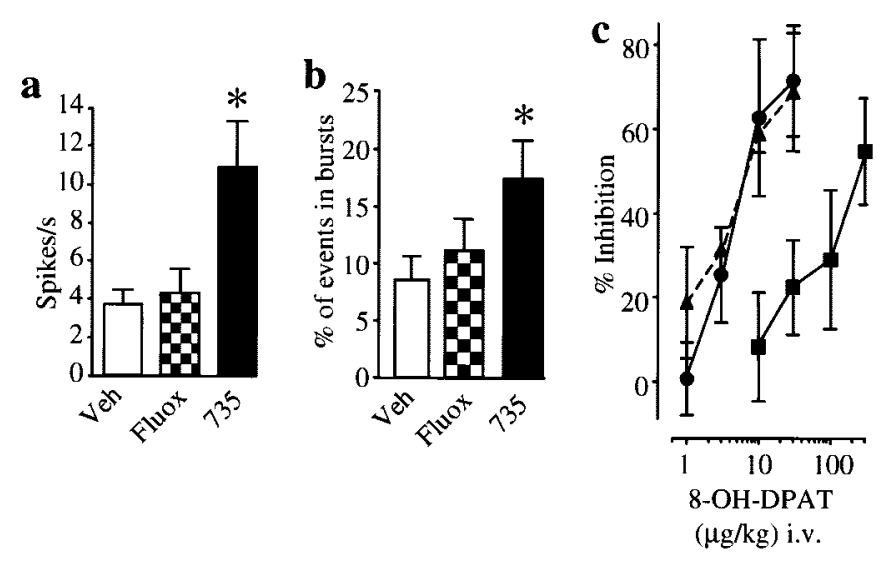

Figure 4. Effects of chronic administration of vehicle, the SSRI fluoxetine $\left(10 \mathrm{mg} \cdot \mathrm{kg}^{-1} \cdot \mathrm{d}^{-1}\right)$, or the $\mathrm{NK}_{1}$ receptor antagonist L-760735 (3 $\mathrm{mg} \cdot \mathrm{kg}^{-1} \cdot \mathrm{d}^{-1}$ ) for $28 \mathrm{~d}$ on DRN neuronal firing. $a, b$, Spontaneous firing rates and incidence of burst firing activity significantly increased after treatment with L-760735 $(* p<0.05$, L-760735 vs vehicle; ANOVA followed by Dunnett's $t$ test). Veh, Vehicle; Fluox, fluoxetine; 735, L-760735. $c$, The dose-response curve to the 5-HT $\mathrm{HA}_{1 \mathrm{~A}}$ receptor agonist 8-OH-DPAT was shifted to the right in animals treated with fluoxetine (ם) compared with those treated with vehicle $(\mathbf{O})$ or L-760735 (A) $(p<$ 0.01 , indicating that only fluoxetine caused $5-\mathrm{HT}_{1 \mathrm{~A}}$ autoreceptor desensitization.

\section{Chronic studies}

The spontaneous firing pattern of DRN neurons was indistinguishable in guinea pigs that had been chronically treated with vehicle or with the SSRI fluoxetine $\left(10 \mathrm{mg} \cdot \mathrm{kg}^{-1} \cdot \mathrm{d}^{-1}\right)$. In contrast, the spontaneous firing rate and the number of action potentials that occurred in burst events were markedly increased in animals that had been chronically treated with L-760735 (3 $\mathrm{mg} \cdot \mathrm{kg}^{-1} \cdot \mathrm{d}^{-1}$ ) (Fig. 4). DRN neuronal activity was dose dependently inhibited by intravenous injection of 8-OH-DPAT (1-300 $\mu \mathrm{g} / \mathrm{kg}$ ); the dose-response curve to 8-OH-DPAT was the same in animals that had been chronically treated with either vehicle or $\mathrm{L}-760735$ (ID $_{50}$ values of 7.9 and $8 \mu \mathrm{g} / \mathrm{kg}$, respectively) and in naive animals $\left(\mathrm{ID}_{50}, 7.2 \mu \mathrm{g} / \mathrm{kg}\right)$. In contrast, the dose-response curve to 8-OH-DPAT was shifted to the right in the fluoxetinetreated group $\left(\mathrm{ID}_{50}, 306 \mu \mathrm{g} / \mathrm{kg}\right.$ ) (Fig. 4), indicating 5-HT autoreceptor desensitization.

\section{Iontophoretic studies}

Microiontophoretic application of L-760735 into the LHb caused a large ( $\sim 2.5$-fold) increase in DRN neuronal firing rate in 8 of 11 cells studied; there was no effect of L-760735 on the three other cells examined. L-770765 was applied to five of the sites within the habenula where L-760735 was active and was without effect (Fig. 5). Application of L-760735 into areas adjacent to the $\mathrm{LHb}$ also had no effect.

\section{Expression of $\mathrm{NK}_{\mathbf{1}}$ receptors in DRN and LHb}

Immunocytochemistry revealed only sparse expression of $\mathrm{NK}_{1}$ receptors in the guinea pig DRN; this pattern of expression resembles that seen in primate brain (Fig. $6 a-c$ ) but is in marked contrast to the rat, where there is a high density of $\mathrm{NK}_{1}$ receptors (Vigna et al., 1994). Unlike in the DRN, $\mathrm{NK}_{1}$ receptor immunoreactivity is prominent in the $\mathrm{LHb}$ of the guinea pig and primate (Fig. $6 d-f$ ), where each displays somatodendritic labeling characteristic of a postsynaptic localization. 

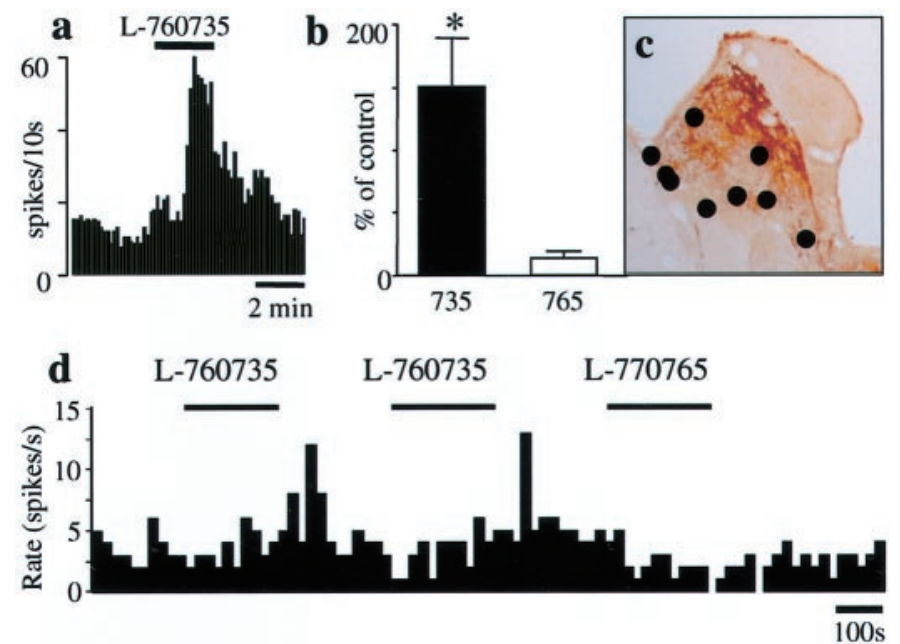

Figure 5. Effects of intrahabenular application of the $\mathrm{NK}_{1}$ receptor antagonist L-760735 on DRN neuronal firing. L-760735 was iontophoresed into the $\mathrm{LHb}$ at currents of up to $+80 \mathrm{nA}$. $a$, The effects on a representative DRN cell. $b$, The mean data $(n=5-11$ cells from 8 guinea pigs). The lower affinity analog L-770765 was ejected at the same polarity and current as L-760735 as a control. $* p<0.05$ between the effects of L-760735 and L-770765; Mann-Whitney $U$ test. $c$, The location of the microiontophoretic pipette tips in the LHb. $d$, A recording from a representative DRN cell in response to intrahabenular application of L-760735 followed by L-770765.

\section{Effects of L-760735 on brain metabolic activity}

L-760735 (3 mg/ kg) caused an increase in neuronal activity, measured as regional increases in metabolic rate, in the amygdala, DRN, LHb, and cingulate cortex when compared with animals treated with vehicle. No changes were seen in the striatum or inferior colliculi. The less active enantiomer L-781773 (3 mg/kg) produced no significant increases in metabolism in the regions examined (Fig. 7).

\section{Effects of L-760735 on 5-HT receptors and transporters in vitro}

L-760735 was not active in human and rodent assays of monoamine oxidase $\mathrm{A}$ and $\mathrm{B}$, the $5-\mathrm{HT}$ transporter, or $5-\mathrm{HT}_{1 \mathrm{~A}}, 5-\mathrm{HT}_{2}$, $5-\mathrm{HT}_{3}, 5-\mathrm{HT}_{4}, 5-\mathrm{HT}_{5}, 5-\mathrm{HT}_{6}$, and $5-\mathrm{HT}_{7}$ receptors $\left(\mathrm{IC}_{50},>3 \mu \mathrm{M}\right)$.

\section{DISCUSSION}

These data show that a highly selective $\mathrm{NK}_{1}$ receptor antagonist can alter the firing pattern of DRN neurons in a manner that is distinct from that seen with fluoxetine. Our findings suggest that SPAs may regulate the firing of ascending 5-HT neurons in the DRN and alter activity in forebrain circuits involved in integrating stress and fear processing. These actions may contribute to the antidepressant effects of SPA treatment.

The first series of in vitro electrophysiological experiments investigated whether the SPA L-760735 had direct actions on 5-HT neurons in the DRN. The membrane potential of 5-HT neurons, identified by their hyperpolarizing response to the $5-\mathrm{HT}_{1 \mathrm{~A}}$ receptor agonist 8-OH-DPAT, was unaffected by application of SP or L-760735 to the DRN slices. These observations, supported by data from the immunocytochemical study, suggest that $\mathrm{NK}_{1}$ receptors are not present on 5-HT neurons in the guinea pig DRN.

A series of in vivo electrophysiological experiments was then performed to examine the effect of L-760735 on the spontaneous activity of neurons in the DRN of anesthetized guinea pigs. Both acute and chronic treatment with L-760635 significantly increased the firing rate of DRN neurons, an observation that is consistent with data from NK1R-/- mice (Santarelli et al., 2001). Recent studies with NK1R - / - mice have also identified clear desensitization of $5-\mathrm{HT}_{1 \mathrm{~A}}$ autoreceptors, evidenced by a reduction in the potency of 8-OH-DPAT to inhibit both DRN neuronal firing and hypothermia and by a reduction in $8-\mathrm{OH}-\left[{ }^{3} \mathrm{H}\right] \mathrm{DPAT}$ binding (Froger et al., 2001; Santarelli et al., 2001). However, in the present study, chronic treatment with L-760735 did not produce any detectable desensitization of $5-\mathrm{HT}_{1 \mathrm{~A}}$ autoreceptors as measured by 8-OH-DPAT-induced neuronal inhibition. This discrepancy may reflect species or methodological differences or a developmental adaptation in the $\mathrm{NK} 1 \mathrm{R}-/-$ rather than a true desensitization of the autoreceptor. Additional studies are required to examine other markers of $5-\mathrm{HT}_{1 \mathrm{~A}}$ autoreceptor function in guinea pigs after chronic SPA treatment.

After chronic treatment with L-760735, DRN neurons also displayed an increased incidence of burst firing. This observation may explain why the SPA-induced increase in spontaneous firing in the DRN did not lead to 5-HT $\mathrm{HA}_{\mathrm{A}}$ autoreceptor desensitization. Previous work has shown that low-frequency stimulation evokes 5-HT release in the DRN that is associated with $5-\mathrm{HT}_{1 \mathrm{~A}}$ autoreceptor control, whereas the release evoked by the same number of stimuli delivered at high frequencies (bursts at $50 \mathrm{~Hz}$ ) is relatively unaffected (O'Connor and Kruk, 1991). Thus, phases of highfrequency bursting activity may produce peaks in 5-HT concentration that, although larger in amplitude than those produced during tonic activity, are rapidly normalized by the 5-HT reuptake mechanism during the interburst interval and are less likely to contribute to activation of $5-\mathrm{HT}_{1 \mathrm{~A}}$ autoreceptors.

Having shown that L-760735 had no direct effect on neuronal firing in the DRN, we performed an immunocytochemical study to identify those brain regions with high densities of $\mathrm{NK}_{1}$ receptors in which L-760735 might act to modulate DRN activity. Immunocytochemistry revealed only sparse expression of $\mathrm{NK}_{1}$ receptors in the guinea pig DRN. Similarly, low levels of $\mathrm{NK}_{1}$ receptors were detected in the primate DRN, in contrast to the high levels seen in the rat DRN (Saffroy et al., 1994), further supporting the guinea pig as a species with $\mathrm{NK}_{1}$ receptor pharmacology and CNS distribution that closely resembles that in primates. These observations suggest that SPAs are unlikely to have direct effects on DRN neurons in humans, and hence, changes in DRN neuronal firing induced by SPAs are likely to result from blockade of $\mathrm{NK}_{1}$ receptors elsewhere in the brain. Unlike the DRN, several midbrain and forebrain structures that mediate stress responses have high densities of $\mathrm{NK}_{1}$ receptors, and among these is the $\mathrm{LHb}$, an area of particular interest because it provides the main link between the forebrain and the DRN (Sutherland, 1982). The immunocytochemical experiments in the present study confirmed that high levels of $\mathrm{NK}_{1}$ receptors are expressed in the $\mathrm{LHb}$ of the guinea pig and primate, and furthermore, the 2-DG experiments revealed that treatment with L-760735 caused a large increase in activity in the LHb, as well as the DRN. Based on these observations, we speculated that direct application of L-760735 into the LHb might increase DRN neuronal firing in the anesthetized guinea pig. Indeed, in an in vivo electrophysiological study, we found that microiontophoretic application of L-760735 into the LHb caused a large increase in DRN neuronal firing rate, whereas application of L-760735 into areas adjacent to the $\mathrm{LHb}$ had no effect.

Extrinsic modulation of DRN function by the LHb has been reported previously (Wang and Aghajanian, 1977a) and has been 

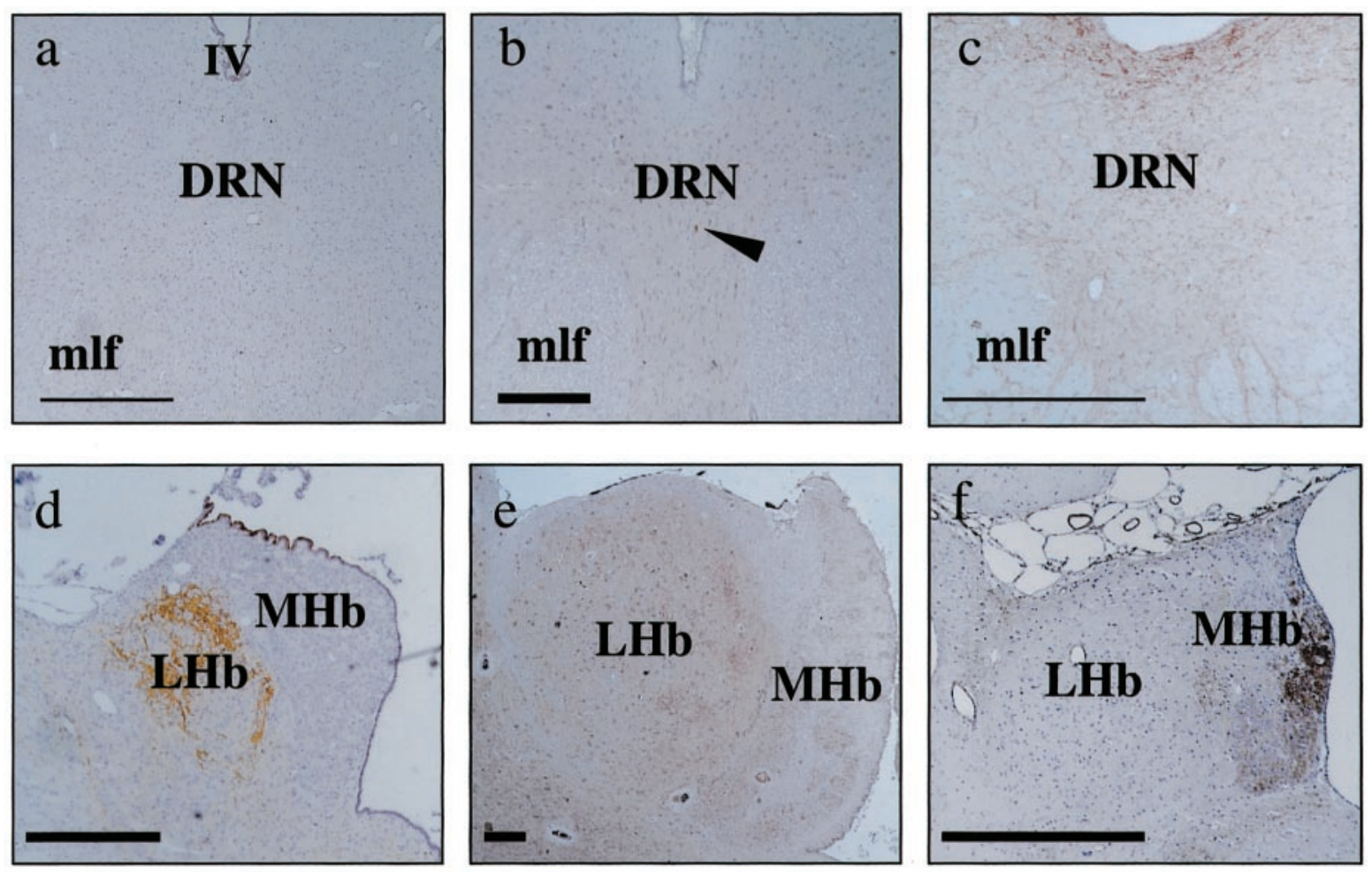

Figure 6. Immunocytochemical determination of $\mathrm{NK}_{1}$ receptor expression in the DRN and LHb of guinea pig and rhesus monkey brain. The DRN of the guinea pig and cynomolgus monkey $(a, b)$, in contrast to the rat $(c)$, shows little $\mathrm{NK}_{1}$ receptor immunoreactivity, with only scattered nonmonoaminergic cells labeled (arrowhead, $b$ ). $\mathrm{NK}_{1}$ receptor immunoreactivity is prominent in the LHb of the guinea pig $(d)$ and primate $(e)$ but not in the rat $(f)$. Scale bars: $a-c, 200 \mu \mathrm{m} ; d-f, 250 \mu \mathrm{m}$. $M H b$, Medial habenula; $I V$, fourth ventricle; $m l f$, medial longitudinal fasiculus.

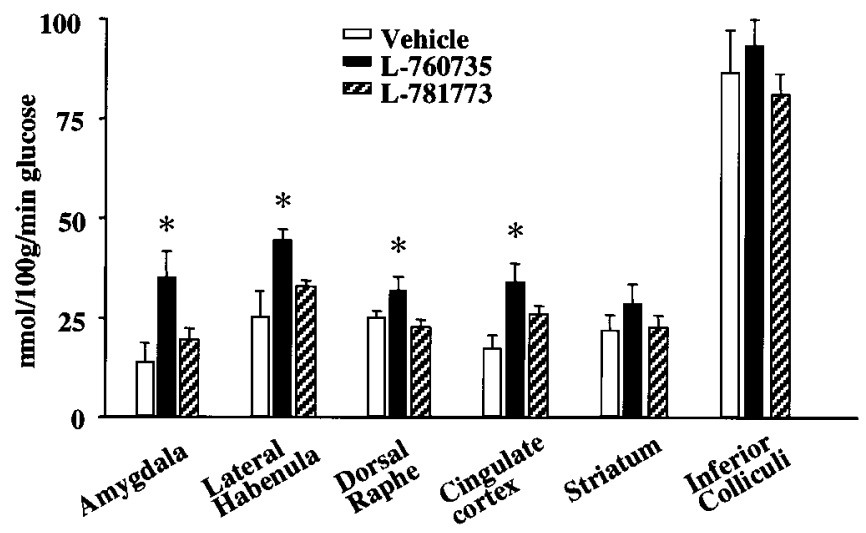

Figure 7. Effects of the $\mathrm{NK}_{1}$ receptor antagonist L-760735 on brain metabolic activity using $2-\left[{ }^{14} \mathrm{C}(\mathrm{U})\right]$ deoxyglucose measurements. The changes in glucose utilization of various brain regions are shown after acute administration of vehicle $(n=4)$, L-760735 (3 mg $/ \mathrm{kg} ; n=5)$, or its enantiomer L-771783 (3 mg/kg; $n=6)$. Data are shown as mean \pm SEM. $* p<0.05$, ANOVA followed by Dunnett's $t$ test. After treatment with L-760735, glucose utilization significantly increased in the LHb and DRN, as well as other areas associated with stress and fear processing, such as the amygdala and cingulate cortex.

confirmed recently in the human brain (Morris et al., 1999). Efferents from the $\mathrm{LHb}$ form the main forebrain projection to the DRN and exert a functional inhibitory tone on neuronal activity (Wang and Aghajanian, 1977a; Reisine et al., 1982; Ferraro et al., 1996). In turn, ascending 5-HT projections from the DRN can modulate stress responses in target forebrain regions that send outputs to the LHb. For example, electrical stimulation of the
DRN inhibits neurons in the amygdala (Wang and Aghajanian, 1977b), and direct injection of 5-HT into the medial amygdala reduces defensive rage (Rodgers, 1977), possibly via an SPcontaining projection to the medial hypothalamus (Shaikh et al., 1993). To complete the circuit, the main inputs to the LHb arise from the amygdala and other serotonergic regions in the forebrain, such as the hypothalamus and reticulopontine nucleus (Sutherland, 1982; Felton et al., 1999), thus providing the pathways for a feedback loop involving forebrain regions that express $\mathrm{NK}_{1}$ receptors, coordinate stress responses, and regulate activity in the LHb and DRN (Fig. 1). The in vivo electrophysiological and 2-DG data from the present study show that SPA treatment increases neuronal activity in the amygdala, LHb, and DRN, lending support to the potential involvement of this circuit in the antidepressant actions of SPAs.

A proportion of inputs to the $\mathrm{LHb}$ could also arise directly from the DRN, because it has been reported that 5-HT neurons innervate the ventricular surface of the habenula in the human brain (Richards et al., 1981). Because many 5-HT neurons in the human brain also contain SP, SPAs may block the effects of SP released via the forebrain-habenula loop. Moreover, because only $50 \%$ of ascending DRN 5-HT neurons coexpress SP in the human brain (Sergeyev et al., 1999), SPAs may provide a regionally specific regulation of 5-HT neuronal function that is distinct from the global changes in 5-HT systems produced by SSRIs that may contribute to mechanism-based side effects.

The 2-DG experiments in the present study also showed that SPA treatment increased metabolic activity in the cingulate cortex. Previous work has identified that changes in cingulate activity correlate with responsiveness to established antidepressant ther- 
apies in patients with Major Depressive Disorder (Pizzagalli et al., 2001). The observation that L-760735 increased activity in several brain regions suggests that SPAs may act at multiple levels in the forebrain and midbrain to regulate circuits involved in stress and fear processing.

The final series of experiments showed that L-760735 had no affinity for a range of 5-HT receptors or transporters in vitro and was not active in assays of monoamine oxidase $\mathrm{A}$ and $\mathrm{B}$. These observations confirm that the effects of L-760735 on 5-HT neuronal activity were not mediated by direct interactions with 5 -HT receptors or transporters and were not secondary to changes in monoamine metabolism.

In summary, our findings show that SPAs are able to modify DRN neuronal activity by a mechanism that is distinct from that of established antidepressant drugs. An increase in DRN neuronal firing rate was seen after both acute and chronic administration of L-760735, indicating that endogenous SP participates in a functional inhibition of this nucleus, as has been suggested by previous studies (Neckers et al., 1979; Reisine et al., 1982). These observations are consistent with reports of an increase in DRN neuronal firing in NK1R-/- mice (Santarelli et al., 2001). The increased neuronal discharge rate was accompanied by a change in the firing pattern of DRN neurons to a burst firing mode. This pattern of firing has been reported previously in DRN 5-HT neurons (Hajos et al., 1995; Hajos and Sharp, 1996, 1997) and is thought to be associated with more efficacious synaptic transmission (Gartside et al., 2000). It has been shown recently that the neuropeptide brain-derived neurotrophic factor also causes burst firing (Celada et al., 1996) and an increase in 5-HT release (Siuciak et al., 1996) in the DRN and has antidepressant-like properties in animal assays (Altar, 1999).

In addition to their direct actions in the amygdala and its efferent projections through which stress responses are coordinated, the effects of SPAs on DRN neuronal activity provide a second mechanism by which these compounds could exert psychotherapeutic actions to alleviate depression. A significant advantage of SPAs is that they do not cause a 5-HT hyperstimulation syndrome, and so the dose may be escalated with greater safety and less risk of side effects than for monoamine reuptake inhibitors.

\section{REFERENCES}

Altar CA (1999) Neurotrophins and depression. Trends Pharmacol Sci 20:59-61.

Baker KG, Halliday GM, Hornung JP, Geffen LB, Cotton RG, Tork I (1991) Distribution, morphology and number of monoaminesynthesizing and substance P-containing neurons in the human dorsal raphe nucleus. Neuroscience 42:757-775.

Barton CL, Jay MT, Meurer L, Hutson PH (1999) GR205171, a selective NK1 receptor antagonist attenuates stress-induced increase of dopamine metabolism in rat medial prefrontal cortex. $\mathrm{Br} \mathrm{J}$ Pharmacol 126:284P.

Bel N, Artigas F (1993) Chronic treatment with fluvoxamine increases extracellular serotonin in frontal cortex but not in raphe nuclei. Synapse 15:243-245.

Beresford IJM, Birch PJ, Hagan RM, Ireland SJ (1991) Investigation into species variants in tachkinin NK1 receptors by use of the nonpeptide antagonist, CP-96,345. Br J Pharmacol 104:292-293.

Berger P, Elsworth JD, Arroyo J, Roth RH (1990) Interaction of $\left[{ }^{3} \mathrm{H}\right]$ GBR12935 and GBR12909 with the dopamine uptake complex in nucleus accumbens. Eur J Pharmacol 177:91-94.

Blier P, de Montigny C (1994) Current advances and trends in the treatment of depression. Trends Pharmacol Sci 15:220-226.

Boja JW, Mitchell WM, Patel A, Kopajtic TA, Carroll FI, Lewin AH, Abraham P, Kuhar MJ (1992) High-affinity binding of [ $\left.{ }^{125} \mathrm{I}\right] \mathrm{RTI}$-55 to dopamine and serotonin transporters in rat brain. Synapse 12:27-36.

Celada P, Siuciak JA, Tran TM, Altar CA, Tepper JM (1996) Local infusion of brain-derived neurotrophic factor modifies the firing pattern of dorsal raphe serotonergic neurons. Brain Res 712:293-298.
Cesura AM, Bertocci B, Da Prada M (1990) Binding of $\left[{ }^{3} \mathrm{H}\right]$ dihydrotetrabenazine and $\left[{ }^{125} \mathrm{I}\right]$ azidoiodoketanserin photoaffinity labeling of the monoamine transporter of platelet 5-HT organelles. Eur J Pharmacol 186:95-104.

Charara A, Parent A (1998) Chemoarchitecture of the primate dorsal raphe nucleus. J Chem Neuroanat 15:111-127.

Cicchetti F, Gould PV, Parent A (1996) Sparing of striatal neurons coexpressing calretinin and substance P (NK1) receptor in Huntington's disease. Brain Res 730:232-237.

de Felipe C, Herrero JF, O'Brien JA, Palmer JA, Doyle CA, Smith AJ, Laird JM, Belmonte C, Cervero F, Hunt SP (1998) Altered nociception, analgesia and aggression in mice lacking the receptor for substance P. Nature 392:394-397.

Felton TM, Linton L, Rosenblatt JS, Morell JI (1999) First and second order maternal behavior related afferents of the lateral habenula. NeuroReport 10:883-887.

Ferraro G, Montalbano ME, Sardo P, La Grutta V (1996) Lateral habenular influence on dorsal raphe neurons. Brain Res Bull 41:47-52.

Froger N, Gardier AM, Moratalla R, Alberti I, Lena I, Boni C, de Felipe C, Rupniak NMJ, Hunt SP, Jacquot C, Hamon M, Lanfumey L (2001) 5-hydroxytryptamine (5-HT)1A autoreceptor adaptive changes in substance $\mathrm{P}$ (neurokinin 1) receptor knock-out mice mimic antidepressantinduced desensitization. J Neurosci 21:8188-8197.

Gartside SE, Hajos-Korcsok E, Bagdy E, Harsing LG, Sharp T, Hajos M (2000) Neurochemical and electrophysiological studies on the functional significance of burst firing in serotonergic neurons. Neuroscience 98:295-300.

Gitter BD, Waters DC, Bruns RF, Mason NR, Nixon JA, Howbert JJ (1991) Species differences in affinities of non-peptide antagonists for substance P receptors. Eur J Pharmacol 197:237-238.

Hahn MK, Bannon MJ (1999) Stress-induced c-fos expression in the rat locus coeruleus is dependent on neurokinin 1 receptor activation. Neuroscience 94:1183-1188.

Hajos M, Sharp T (1996) Burst-firing activity of presumed 5-HT neurones of the rat dorsal raphe nucleus: electrophysiological analysis by antidromic stimulation. Brain Res 740:162-168.

Hajos M, Sharp T (1997) 5-HT neurones-bursting with information? Trends Neurosci 20:244

Hajos M, Gartside SE, Villa AE, Sharp T (1995) Evidence for a repetitive (burst) firing pattern in a sub-population of 5-hydroxytryptamine neurons in the dorsal and median raphe nuclei of the rat. Neuroscience 69:189-197.

Jolas T, Haj-Dahmane S, Kidd EJ, Langlois X, Lanfumey L, Fattaccini CM, Vantalon V, Laporte AM, Adrien J, Gozlan H, Hamon M (1994) Central pre- and postsynaptic 5-HT1A receptors in rats treated chronically with a novel antidepressant, cericlamine. J Pharmacol Exp Ther 268:1432-1443

Kramer MS, Cutler N, Feighner J, Shrivastava R, Carman J, Sramek JJ, Reines SA, Liu G, Snavely D, Wyatt-Knowles E, Hale JJ, Mills SG, MacCoss M, Swain CJ, Harrison T, Hill RG, Hefti F, Scolnick EM, Cascieri MA, Cicchi GG, et al (1998) Distinct mechanism for antidepressant activity by blockade of central substance P receptors. Science 281:1640-1645

Krase W, Koch M, Schnitzler HU (1994) Substance P is involved in the sensitization of the acoustic startle response by footshocks in rats. Behav Brain Res 63:81-88.

Kurumaji A, McCulloch J (1989) Effects of MK-801 upon local cerebral glucose utilisation in conscious rats and in rats anaesthetised with halothane. J Cereb Blood Flow Metab 9:786-794.

Morris JS, Smith KA, Cowen PJ, Friston KJ, Dolan RJ (1999) Covariation of activity in habenula and dorsal raphe nuclei following tryptophan depletion. NeuroImage 10:163-172.

Neckers LM, Schwartz JP, Wyatt RJ, Speciale SG (1979) Substance P afferents from the habenula innervate the dorsal raphe nucleus. Exp Brain Res 37:619-623.

O'Connor JJ, Kruk ZL (1991) Frequency dependence of 5-HT autoreceptor function in rat dorsal raphe and suprachiasmatic nuclei studied using fast cyclic voltammetry. Brain Res 568:123-130.

Pizzagalli D, Pascual-Marqui RD, Nitschke JB, Oakes TR, Larson CL Abercrombie HC, Schaefer SM, Koger JV, Benca RM, Davidson RJ (2001) Anterior cingulate activity as a predictor of degree of treatment response in major depression: evidence from brain electrical tomography analysis. Am J Psychiatry 158:405-415.

Reisine TD, Soubrie P, Artaud F, Glowinski J (1982) Involvement of lateral habenula-dorsal raphe neurons in the differential regulation of striatal and nigral serotonergic transmission in cats. J Neurosci 2:1062-1071.

Richards JG, Lorez HP, Colombo VE, Guggenheim R, Kiss D, Wu JY (1981) Demonstration of supra-ependymal 5-HT nerve fibres in human brain and their immunohistochemical identification in rat brain. J Physiol (Paris) 77:219-224.

Rodgers RJ (1977) Elevation of aversive threshold in rats by intraamygdaloid injection of morphine sulphate. Pharmacol Biochem Behav 6:385-390.

Rupniak NM, Carlson E, Harrison T, Oates B, Seward E, Owen S, de 
Felipe C, Hunt S, Wheeldon A (2000) Pharmacological blockade or genetic deletion of substance P (NK1) receptors attenuates neonatal vocalisation in guinea-pigs and mice. Neuropharmacology 39:1413-1421.

Saffroy M, Beaujouan JC, Petitet F, Torrens Y, Glowinski J (1994) Differential localization of ${ }^{3} \mathrm{H}$-[Pro9] SP binding sites in the guinea pig and rat brain. Brain Res 633:317-325.

Santarelli L, Gobbi G, Debs P, Sibille E, Blier P, Hen R, Heath M (2001) Genetic and pharmacological disruption of neurokinin 1 receptor function decreases anxiety related behaviors and increases serotonergic function. Proc Natl Acad Sci USA 98:1912-1917.

Sergeyev V, Hokfelt T, Hurd Y (1999) Serotonin and substance P coexist in dorsal raphe neurons of the human brain. NeuroReport 10:3967-3970.

Shaikh MB, Steinberg A, Siegel A (1993) Evidence that substance P is utilized in medial amygdaloid facilitation of defensive rage behavior in the cat. Brain Res 625:283-294.

Siuciak JA, Boylan C, Fritsche M, Altar CA, Lindsay RM (1996) BDNF increases monoaminergic activity in rat brain following intracerebroventricular or intraparenchymal administration. Brain Res 710:11-20.

Sokoloff L, Reivich M, Kennedy C, Des Rosiers MH, Patlak CS, Pettigrew KD, Sakurada O, Shinohara M (1977) The $\left[{ }^{14} \mathrm{C}\right]$ deoxyglucose method for the measurement of local cerebral glucose utilization: theory, procedure and normal values in the conscious and anesthetized albino rat. J Neurochem 28:897-916.

Sutherland RJ (1982) The dorsal diencephalic conduction system: a review of the anatomy and functions of the habenular complex. Neurosci Biobehav Rev 6:1-13.

Tejani-Butt SM, Brunswick DJ, Frazer A (1990) $\left[{ }^{3}\right.$ H]nisoxetine: a new radioligand for norepinephrine uptake sites in brain. Eur J Pharmacol 191:239-243.

Vertes RP (1991) A PHA-L analysis of ascending projections of the dorsal raphe nucleus in the rat. J Comp Neurol 313:643-668.

Vigna SR, Bowden JJ, McDonald DM, Fisher J, Okamoto A, McVey DC, Payan DG, Bunnett NW (1994) Characterization of antibodies to the rat substance $\mathrm{P}$ (NK-1) receptor and to a chimeric substance $\mathrm{P}$ receptor expressed in mammalian cells. J Neurosci 14:834-845.

Wang RY, Aghajanian GK (1977a) Physiological evidence for habenula as major link between forebrain and midbrain raphe. Science 197:89-91.

Wang RY, Aghajanian GK (1977b) Inhibition of neurons in the amygdala by dorsal raphe stimulation: mediation through a direct serotonergic pathway. Brain Res 120:85-102. 